\title{
ВЛАДЕТА ЈЕРОТИЋ
}

Српска академија наука и уметности, Београд

DOI 10.5937/kultura1340018J

УДК 159.923.2:27-18

141.319.8:27-18

101.8

оригиналан научни рад

\section{HEMA CA3PEBAHA БE3 CTУПАНААУ ДИЈАЛОГС СА ЂУПИМА СУПРОТНОГ MMU山bEHA}

Сажетак: Телесно душевно-духовно сазревање појединия /не и народа/ дуг је, мучан и целоживотан процес. Мноштво је чинилаца у току живота човека који овај прочес сазревања, односно осмииьвавана живота /,, воља за смислом”/могу да убрзају или успоре. Мало је сумье било и остало код психолога, психотерапеута, философа и религиозних мислилаца да је дијалог са људима друкчијег животног уверења /религиозног и идејног/ поуздан пут стварне индивидуације и/или обожења човека. Стално животно богаћење свога духовног, интелектуалног, али и емотивног/ираџионалног/ бића, на трновитој стази човека путника /хомо виатор/ условљава пораст толеранције према Другом и Другачијем.

Кључне речи: сазревање, дијалог, психологија, психијатрија, филофозија, религија

Дуалистичко гледиште на човеково биће, било оно само философско или и религиозно, оправдано је јер га психичка реалност стално потврђује. Човек је најсложеније живо биће у природи, оно је и телесно и душевно и духовно. Подела човекове суштине на тело и душу, како је Платонова философија сматрала, за неке философско-религиозне мислиоце значајно је допуњена, за друге непотребно компликована, 


\section{ВЛАДЕТА ЈЕРОТИЋ}

Аристотеловом тезом о човеку као јединству тела, душе и духа. ${ }^{1}$

Развој психологије као науке, иако привидно закаснео (у односу на развој других наука) - нарочито развој тзв. дубинске психологије од почетка XX века - прећутно је потврдио споменуту Аристотелову поставку о стварном постојању (и разлике и јединства) телесних, душевних и духовних функција у човековој природно-духовној суштини. У Новом завету има места која би говорила у прилог овакве трочлане поделе људског ипостаса (нарочито приметно у Павловој посланици Солуњанима 5, 43).

Било како било, нико од људи не може да посумња (из личног доживљеног искуства) да се унутар човековог бића води, готово непрекидно, јача или слабија, свесна или несвесна борба „душе са телом” („У њ ратује душа са тијелом... борба непрестана" - Његош). Шта то хоће душа (а тек дух!) што неће тело, и обратно? Који је од ова два (или три) ентитета ближи „принципу задовољства” (овоме је принципу подвргнуто свако живо биће и то од самог рођења), а који „принципу реалности”? Али, поставља се много теже питање: Шта је реалност? Да ли само оно што видимо, чујемо, додирујемо, дакле оно што је чулима видљиво, или постоји и нешто чулима недохватљиво, невидљиво, па и неразумљиво? Када људи говоре о души и/или духу, мало је њих који би знали и умели, бар приближно, да ближе одреде шта подразумевају под појмом душе. Значи ли ово да сваки човек (био он тога свестан или не) стоји пред трајном загонетком унутар сопственог бића које се непрестано оглашава, час телесно, час душевно, а онда и духовно? Само ретко (у неким блаженим тренуцима) човек доживљава јединство (слогу, помирење) тела, душе и духа. Сви остали, далеко бројнији дани, године, векови у животу човека (његовог народа и опште историје) испуњени су и препуњени су, сталном борбом - борбом захваљујући којој се једино можда може достићи жељено, чежњиво жељено Ј(j)единство тела, душе и духа.

Овај кратак Увод био ми је потребан да предочим читаоцу неопходност, још и више, смисаоност, више пута овде спомињане, непрестане борбе супротстављених сила унутар нашег невидљивог и видљивог бића. Пошто је апсолутно немогуће да човек остане целог живота у „принципу задовољства" (као присутног биолошког стожера блиског нагону

1 На VIII Васељенском сабору у Константинопољу 787. године, који православна црква не признаје, поменута Аристотелова теза и званично је за римокатоличку цркву (много касније и за протестантску) прихваћена, иако до поделе цркава још није било дошло. 
самоодржања) - мада неки савремени психолози тврде да је од самог почетка живота детета у њему упоредо присутан и „принцип реалности” поред ,принципа задовољства” - задатак је човека (,човек је дат и задат!”) да у току свог живота истражује суштину тзв. реалности, тј. да открива реалност постојања у њему, душе и духа. И, да поновимо: ово доживотно упознавање тзв. реалности (видљиве и невидљиве), немогуће је замислити без борбе, односно без дијалога са супротним у себи. Ово супротно, и видљиво и невидљиво, присутно је како унутар сопственог телесно-душевно-духовног живота, тако је оно присутно и у ближем или даљем окружењу човека, у спољашњем свету; тај спољашњи свет представљен је (већ од рођења) родитељима, народом у коме је човек рођен, његовом традицијом, религиозном и световном.

Одавно знамо да је процес сазревања човека-појединца (а тек сазревање народа, ако постоји!) веома сложен и доживотан процес. Никад није постојао неки човек (нека је он био и генијалан) који је достигао неки замишљени ступањ потпуне зрелости (од Христа јасно постављен циљ човековог живота). Ми смо сви само на путу сазревања (да ли сви?), а према коме или чему је управљано сазревање, каквог смисла уопште има процес зрења? Одговор на ово, мислим, збиља важно питање за сваког човека, налази се у природном (и натприродном) тражењу и налажењу „погледа на свет” сваког човека. До одређеног „погледа на свет” (условно речено позитивног или негативног) долази се, најчешће постепено, опет видљивом и невидљивом борбом, подједнако са самим собом (ова борба је важнија и пресуднија за исход борбе) и са људима из своје ближе и даље околине.

Кад год се човек умори од борбе (а не постоји човек који се повремено не умори), прете му бројне опасности у његовом даљем животном току, као што су: равнодушност, апатија, депресија (униније), као исход разочарења у себе, у друге, у Бога (ако се у Њега веровало), односно негирања било каквог смисла живота.

Човек је позван (од кога?) на непрекидно усавршавање (creatio continua, creatio nova - и у самом Богу присутна, јер „Бог не спава”, како вели једна од дубоко смислених српских народних пословица). Ако човек не следи „прогресивно” у себи, осветиће му се оно „регресивно” у њему.

Па, како човек најуспешније напредује ка зрелости (душевној, али значајније, ка духовној зрелости)? Једино у „борби мишљења", у којој борби, разуме се, да и човекове емоције играју значајну улогу - „емотивна интелигенција”. Дакле, 


\section{ВЛАДЕТА ЈЕРОТИЋ}

ирационални део његове личности који је наравно значајан, али ирационално у нама које се може и мора контролисати, поправљати и богатити. Ова неопходна „борба мишљења" одиграва се најпре и најбоље у дијалогу. Не може се довољно позитивно оценити улога и значај вођења дијалога у човековом животу, управо на путу његовог и стварног сазревања.

Дефиницију дијалога треба да одавно знамо: Разговор вођен са човеком супротног мишљења од нашег (није битно да ли је то супротно мишљење религиозне, философске, научне или политичке природе); разговор треба да буде више пута понављан и, важно је, лишен присуства афеката. Резултат овако вођеног дијалога, такође је познат: обогаћивање личности оба учесника у разговору, било у смислу делимично или потпуне промене дотадашњег мишљења (наша мисао често постаје и наша вера, позитивна или негативна, толерантна или нетолерантна), или плодног јачања и учвршћивања дотадашњег мишљења.

Да ли је овако дефинисан појам дијалога могућ једино са собом самим, вођењем унутрашњег дијалога? Да, могућ je, и он је познат код већине великих ствараоца, нарочито у уметности; међу оваквим људима доста је интровертованих (према Јунговој подели типова људи на интровертоване и екстравертоване). Њихова, често драматична и доживотна борба са самим собом у самом себи, доживљава као плод некада велико стваралачко дело. Зар је могуће замислити да су Гетеов „Фауст”, Шекспиров „Хамлет”, Милтонов „Изгубљен и поново нађен рај”, Његошева „Луча микрокозма”, или Бетовенове симфоније, Вагнерове опере и много других драгоцених дела у области уметности, у којима збиља уживају људи од ума и срца (иако сами нису ствараоци) - могли да угледају „светлост дана”, без спомињане драматичне, често и трагичне борбе присутне у оваквим ствараоцима.

Зашто толико много људи у свету бежи од дијалога који их може најбрже да поведе (не до краја и доведе) путем сазревања? Страх је увек био и остао онај најгори мач који витла над главом сваког човека. Страх од упознавања самог себе! Божанског и ђаволског - скоро бих рекао да је тај страх подједнако јак и опасан и при покушају стварног упознавања (приближавања) себе, и Богу и ђаволу. Није битно да ли ђавола има или нема - оваква сумња постојала је, можда, одувек у човеку, али нарочито се оснажила у току трајања историје религија, нарочито хришћанске религије, у којој се претеривало са претњама људима ђаволом и паклом - сваки човек, без обзира којој је религији припадао или не припадао, без обзира у коме се народу родио и какво је васпитање 


\section{ВЛАДЕТА ЈЕРОТИЋ}

добио, слути, али и зна ( ако хоће да зна!) да је у њему стварно присутан и Бог и ђаво, или (мање строго речено) - Добро и Зло.

Први корак ка истинском упознавању себе („Познај самог себе”, од делфијског пророчишта, мада вероватно и пре старих Грка, па до готово свих хришћанских светитеља) јесте упознавање (препознавање) у себи самом врлине и мане, добростивости и греха, једном речи, препознавање у себи доброг и злог човека. Тражење помирења Бога и ђавола, Добра и Зла у себи и у свету (да ли је могуће?) такође је природна (често и нужна) потреба, али и задатак који стоји целоживотно пред Ч(ч)овеком. Мали је број религиозних мислилаца, философа и великих уметника који посвећују цео свој живот одгонетању ове врхунске Тајне.

Завршићу овај мој покушај показивања (да ли и доказивања?) неопходности човека на путу сазревања (а сваки је човек, био он тога свестан или не, на путу прелажења из нижег разреда у виши) да смело и искрено води дијалог са супротним у себи и код другог човека (човека друге националности и нарочито друге религије) - позивањем на апостола Павла из његових посланица. Пажљиво и поновљено читање већине, увек актуелних посланица апостола Павла намењених свим људима и у свим временима - може човека да охрабри да настави ону „непрестану борбу” за коју зна да је присутна и у њему и у свим људима и народима. Настављајући је, човек све боље осмишљава потребу да жели (свим бићем својим) да сазрева, што не значи друго него да се приближава своме Творцу који га воли и који од њега очекује да престане да се боји, јер тек тада човек може да постане оно најлепше - да постане „пријатељ и сарадник Божији”. Ево тих речи апостола Павла (из посланице Римљанима 8, 15, Галатима 4, 7 и II посланице Тимотеју 1, 7):

„Јер не примисте духа ропства, опет да се бојите, него примисте духа посиначког којим вичемо: Ава оче!

Тако већ ниси роб, него син; а ако си син, наследник си Божији, кроз Исуса Христа.

Јер нам Бог не даде духа страха, него силе и љубави и чистоте".

\section{Закьучак}

Телесно душевно-духовно сазревање појединца /не и народа/ дуг је, мучан и целоживотан процес. Мноштво је чинилаца у току живота човека који овај процес сазревања, односно осмишљавања живота /,воља за смислом”/ могу да 
убрзају или успоре. Мало је сумње било и остало код психолога, психотерапеута, философа и религиозних мислилаца да је дијалог са људима друкчијег животног уверења /религиозног и идејног/ поуздан пут стварне индивидуације и/или обожења човека. Стално животно богаћење свога духовног, интелектуалног, али и емотивног/ирационалног/ бића, на трновитој стази човека путника /хомо виатор/ условљава пораст толеранције према Другом и Другачијем.

\title{
ЛИТЕРАТУРА:
}

Свето писмо, Нови завет Господа нашега Исуса Христа, Посланица Светог апостола Павла Солуњанима 5, 43

Свето писмо, Нови завет Господа нашега Исуса Христа, Посланица Светог апостола Павла Римљанима 8, 15

Свето писмо, Нови завет Господа нашега Исуса Христа, Посланица Светог апостола Павла Галатима 4, 7

Свето писмо, Нови завет Господа нашега Исуса Христа, Друга посланица Светог апостола Павла Тимотеју 1, 7

\author{
Vladeta Jerotić \\ Serbian Academy of Sciences and Arts, Belgrade
}

\section{NO MATURITY IS POSSIBLE WITHOUT A DIALOGUE WITH PEOPLE OF THE OPPOSITE OPINIONS}

\begin{abstract}
Reaching maturity of the individual body, spirit and soul /not that of a people/ is a troubled and a lifetime long process. There are multiple factors that may speed up or slow down this process of maturing, i.e. the process of giving sense /"will for sense"/ to one's life. Psychologists, psychotherapists, philosophers and religious thinkers have little doubt left or never had any that a dialogue with people of different life beliefs /religious and ideological/ secure a path to real individualization and/ or divination of a man. A constant enrichment of not only spiritual and intellectual but also emotional /irrational/ being of a individual taking the thorny path of life /homo viator/ raises one's tolerance to the Other and Otherness.
\end{abstract}

Key words: maturing, dialogue, psychology, psychiatry, philosophy, religion 